\title{
The Space Narrated. The Stained Glass Windows of Pietro Chiesa in the Early Twentieth Century ${ }^{\dagger}$
}

\author{
Francesca Castanò * and Giangaspare Mingione \\ Dipartimento di Architettura, Università della Campania “Luigi Vanvitelli”, 81100 Caserta CE, Italy; \\ giangaspare.mingione@gmail.com \\ * Correspondence: francesca.castano@unicampania.it \\ + Presented at the International and Interdisciplinary Conference IMMAGINI? Image and Imagination \\ between Representation, Communication, Education and Psychology, Brixen, Italy, 27-28 November 2017.
}

Published: 10 November 2017

\begin{abstract}
The contribution intends to examine the relationships between the image of the city and its spatial context, real or virtual, through the analysis of Pietro Chiesa's artistic windows (18921948). In its production, the size of the inhabited space, emphasized by small architectural details or elaborate prospective games accentuated by profound chromaticities, is therefore a crucial factor. The windows then allowed the artist to work with the light and with the changing colour effects which it was able to create, depending on the transparency, the changing atmospheres, as well as new sensations and moods. The urban space and the constructions then become the subjects of a new narration portrayed by Pietro Chiesa in an ever-heterogeneous way without using an univocal interpretation, never in controversy with History, projected rather, towards the innovations of the artistic-literary avant-gardes.
\end{abstract}

Keywords: twentieth century; stained glass window; north Italy

\section{Introduction}

«An environment has, by nature, four walls. The environment with a window [...] has instead three walls and an empty» [1].

The introduction of the furnished window, conceived by Gio Ponti as a "fourth wall", integrated with spatial domestic condition, rather than exclusive exterior threshold, announces at the dawn of the twentieth century a design season in which the elements of passage between the private sphere and the public environment acquire new and unreleased meanings. In this season, thanks to the flourishing of arts workshops and the tendency of fine art to intrude in the field of stained glass [2], the transition between interior and exterior-understood as «median medium» [3]-in respect of once again, refound interest for decoration and the exotic taste became the object of new design experiments. Several artists had seen in the design of furniture an unexplored land on which to work on not always giving interesting results; Papini himself infact underlined how the bourgeois windows usually found to be «parrot form» or «rich in the roselike floral style» [4], which puts them to remark now past styles. Pietro Chiesa (1892-1948), master glassmaker and designer of Ticino, played an important interpretative role in executing composition commissioned by the artists in occasion of international exhibitions [5]. In 1923 he participated in the first Biennial of Monza, receiving considerable consideration and approaching the increasingly refined bourgeois taste. In fact, already in 1927 his stained glass for apartments presented in the halls of the Labyrinth and the Domus Nova were referred to as «the most desirable, candid, [...] amongst the modern they are recognised» [6]. The group project brought in a nutshell the idea of a production series assumed for the rising bourgeoisie, in fact with the stained glasses «adaptable to any form of window, possible for any bourgeois house» [7], is combined with furniture designed by Gio Ponti, Emilio Lancia and 
Tomaso Buzzi. One can observe different types of spatial configuration in small windows dating between 1926 and 1932. The first defined «useful windows» [8], respectly depict the summer and the winter, through an immediate representation obtained with only a few lines which represent a fan and a coffee machine. The very neat background is defined by two grades of colour. It is instead resorted to a fantastic space in the small glazed allegorical window realized by Gio Ponti and Pietro Chiesa in about 1932, placed in the bath adjacent to the new officina in Vittoriale [9] (Figure 1a). An exemplary double signature specimen, then reproduced in a small series without any variation in design but with variations in glass and color. The subject, declared ironic, represents a figure of human features but with appearance inspired by the shape of a bean. In the background emerges a starry night rich in chromaticity thanks to the use of precious glasses that define its shapes and details. A symbol which seams to seal the deal of friendship between the two designers, a harbinger of a future collaboration in Fontana Arte [10]. It is interesting to note how the designer uses a more abstract space, with no details, but enriched by lines and colors that impulsively suggest subjects. On larger windows, however, the inhabited space and the size of the building are instead accentuated by architectural details and elaborated with perspective games sublimated by intense colors. The depth of the colors obtained by the skillful use of grisaille, the study of light and transparency generate new sensations and dynamic atmosphere. The home environment is charged of symbolic value by binding the external space through the drawings made of lead, causing the glass to become a transparent and ephemeral threshold, a limen not exclusively physical but also a «transition zone» [11] cultural and spiritual. The glass master, influenced by ongoing collaborations with several artists, portrays the urban space and, more generally, the external environment without following a single line by using diverse interpretations, never against tradition, but without neglecting the innovations of the artistic and literary vanguards.

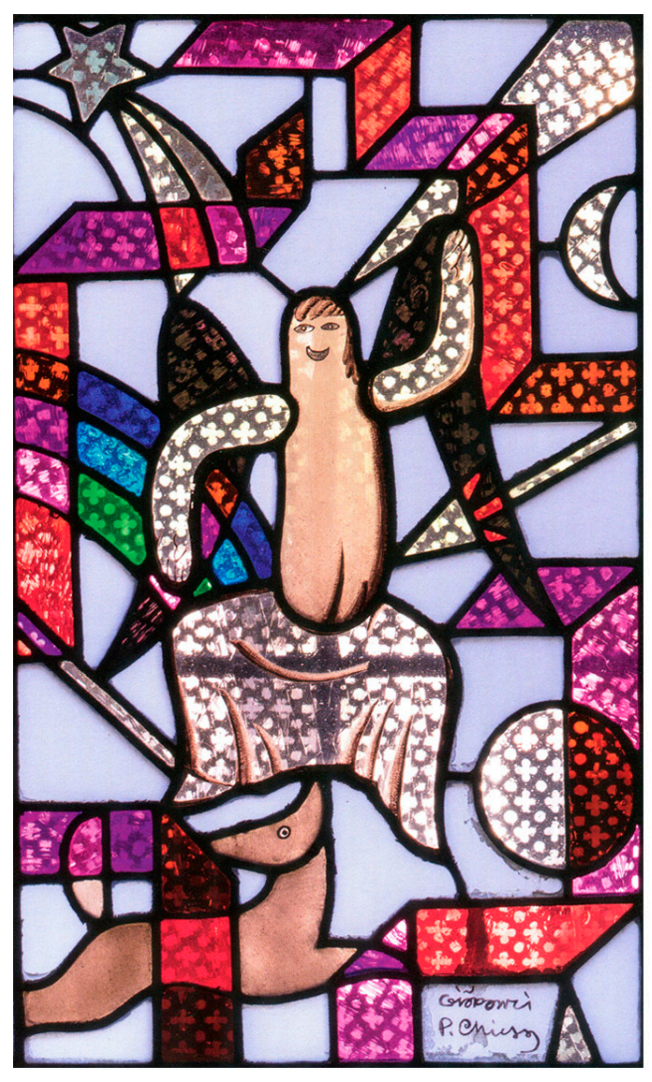

(a)

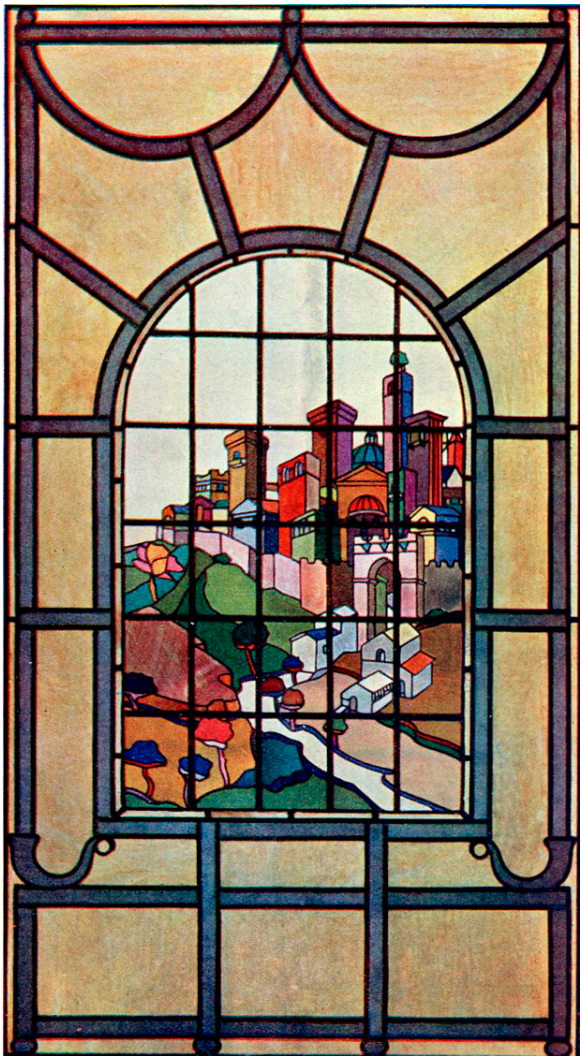

(b)

Figure 1. (a) Pietro Chiesa (execution), composition by Pietro Chiesa and Gio Ponti, Vetrata allegorica, 1932, in AGV. (b) Pietro Chiesa (execution), composition by Buzzi, Paesaggio Umbro, 1925, in G. Marangoni, Le arti del fuoco: ceramica, vetri, vetrate, in Enciclopedia delle moderne arti decorative italiane, Milano, Ceschina, 1927. 


\section{From Umbro Landscape towards the Ideal City}

The success of the works exhibited in the exposition at Monza in 1923 had enabled recognition to Chiesa such an interpretative ability to be considered as an artist and not just a master glassmaker. 1925 was marked-in addition to the renewed appointment Biennial-by another important event, the l'Exposition Internationale des Arts Décoratifs et industriels modernes [12] in Paris, where there was a large number of artists, artisans and industrialists, as was presented a great quantity and variety of objects. Italians, represented in glass industry by Murano Venini Furnace [13], won a Grand Prix helping to honour the name of Italy in the international exhibition. The international exhibitions thus became an 'opportunity to cultural and technological exchange for the artists of the time that could thus have a comparison with what is happening elsewhere. Of the works on display in Paris [14], the window Landscape Umbro (Figure 1b) made on Buzzi's composition [15], opens a season of international successes intended to enhance the fame of the magister Vitrearum [16]. The subject outlined, might seem not very original if you take into account the brightest personalities involved but well describes the evolution of the design of the two figures. The title clarifies that the location of the hypothetical village portrayed - although there are no precise indications about it - is in Umbria; a choice due to one of the most well-known designs of Buzzi, Scarzuola [17], made precisely in Montegiove in the municipality of Montegabbione (TR). It could be said that composition for glass is the result of a preliminary approach with those places that could have inspired later the planning of the Buzzi ideal city. Tradition says that St. Francis had stayed in those areas around 1218 finding shelter under a hut built with a local plant, Scarza. Over the years to commemorate the passage of the saint a convent was erected which in 1956 Buzzi bought to give life to his dream. In the glass the mystical and symbolic references that characterize the Scarzuola project are not yet present, but it is clear the succession of a shared need for interiority, the actual size of the ideal city where «the important thing [...] is more the vase than what's inside» [18]. Pietro Chiesa can translate in a hermetical manner-with an almost geometric coldness - the composition, where the absence of grisaille generates a total absence of volumetric perception punctuated only by ligation of lead. The flat colors and the absence of shadows give rise to an unrealistic landscape-a village suspended in time-still as if it were crystallized. If nature appears untouched and lush, the environment built within the walls instead becomes more dense by staging a sequence of similar volumes to the spiers and to the shapes of the characteristics of the Scarzuola landscape. The composition of the glass by virtue perspective illusion of a "window in the window", generates a spatial depth as if to emphasize the physical value of the threshold. In this way, what is beyond the glass seems to be even further away from our reach, thus drawing a metaphorical spiritual path to the much-awed Buzzy interiority. In 1927 Pietro Chiesa became part of the association to spread in the house of modern and fine arts Il Labirinto with Paolo Venini, Gio Ponti, Carla Visconti di Modrone, Emilio Lancia and Tomaso Buzzi, taking part in the third Biennial of Monza, receiving an encomium for his «monochrome glass windows in the lounges [...] delightful and precious opal tones» [19]. The international exhibitions represented a precious opportunity to explore the state of the art and highlight, critically, the differences between the different designers and companies. Indeed, if Chiesa was praised for the «tone preciousness achieved with overlays, the clarity of the design emphasized by the lead», on the contrary Cappellin was accused of having with its stained glass windows «theatres of boys and nativity scenes in country churches» [20].

\section{Strapaese and Stracittà: From the Roman Acropolis to the Vertical City}

If the Monza Biennials represented a careful lens through which to read the new trends in architecture and decorative arts, the Venice Biennial, on the other hand, could boast of a consolidated historical tradition, dating back to 1895 . Both international exhibitions every two years were differed for conducting themes,in fact, if the first institution was linked to the world of decorative arts, the second focused on art and architecture in general. While analyzing this dimention, it would be reductive to find within these large cultural basins a boundary well defined among the different skills. Pietro Chiesa, thanks to the trasversal theme of the glass, rappsents an emblematic case for the designer, both the art world and in the decorative arts. 
Ugo Nebbia, referring to the Venetial Biennial of 1924, emphasized how much glass was well represented in the exhibition, «this time tied up and composed of the now-assured art of the young Pietro Chiesa [...] on his designs, or even those of Vittorio Zecchin Emilio Lancia, Angiolo D'Andrea and Aldo Carpi» [21]. Despite not having yet reached maturity, he could already impress the critics of the time thanks to his "wise stained-glass windows» and was cooperating with a high level entourage. In the next ediction, he was drawn to the attention of the public with an 'impressive work composed by two stained glass windows on a design by Salvatore Saponaro and Tomaso Buzzi, the other Ubaldo Oppi, framed by the death drawn by the same Chiesa. Returning from the success of 1926, two years after Chiesa had the opportunity to exhibit in a room all of his own [22] of which he also chose the architectural disposition. The square plan of the environment for the exhibition was modified through the «shapes of rough plaster» [23], thus assuming an octagonal shape.

At the center of the room was a bronze sculpture by Antonio Maraini, entitled Bagnante, and on the walls around were Chiesa's windows (Figure 2). The most important, regarding to the theme, are Strapaese (Figure 3a) and Stracittà (Figure 3b), respectively on Achille Funi and Tomaso Buzzi's composition, representative of a contrasting cultural and literary climate in which the two movements took life. The two themes «art and literature not only of an immediate yesterday but a more remote time», represented «a contrary view, not only of art, but of the world and of life» [24]. The contrast, predominantly fed by differences «in prose and in verse», was in Carducci and in the current of the «manzonismo» [25] his most famous exponents. The advent of modernity aimed «to immerse themselves in art forms refusing or caring very little for Tradition» [26] had tightened this divergence creating two factions; in particular the Stracittadini claimed that the style «must be found in the modern world we live in», the Strapesani stated instead that it was to be found «if not exactly in the ancient». The diversity of their movements is also reflected in the windows, animated by stylistic elements and completely different shapes. The first is characterized by a background intense cobalt tones in which the figures and animals appear "suspended", without there being any attempt to frame a space devoid of any prospective reference. Under the sun and the moon, the stars that characterize rural life, parading in a disorderly manner typical subjects of a still agricultural countryside, dedicated to cultivation and farming. Impressive the use and the charge of the chromaticities that are so contrasting, to the point of clashing with the space-time calm of the glass. The second glazed, Stracittà, is rich in an upward tension, a force almost "vector", as indicated at the top by an arrow. A strong appeal to the work of futurism, a powerful modernity made of obelisks with metallic and reticular structures, signs which emerge from one another close to the other as in a chaotic contemporary metropolis. All this, however, opposes a latent nostalgia for the classical world, in fact the window is full of temples, pyramids, statues, mannequins, strong connections with the metaphysical hemisphere. An angel with his shrilling trumpet dominates the scene, derived from the opening of a large scroll.

In the background the Roman acropolis-where you recognize the Pantheon, the Colosseum, Marcello's theatre, Trajan's column, the Cestius pyramid, an obelisk three triumphal arches-which seem to prefigure the acropolis of Scarzuola [27]. Singular signatures of Buzzi and Chiesa who become the occasion for both brands in the cosmopolitan metropolis of Stracittà. The spatial dimension is therefore very complex, and in this light the topos of the city is proposed in two different variants: the Roman acropolis that stands in the background-hetairia and light volumes-while in the foreground an energetic city comes to life, dramatic, moving-almost futuristic-with vertical development. 


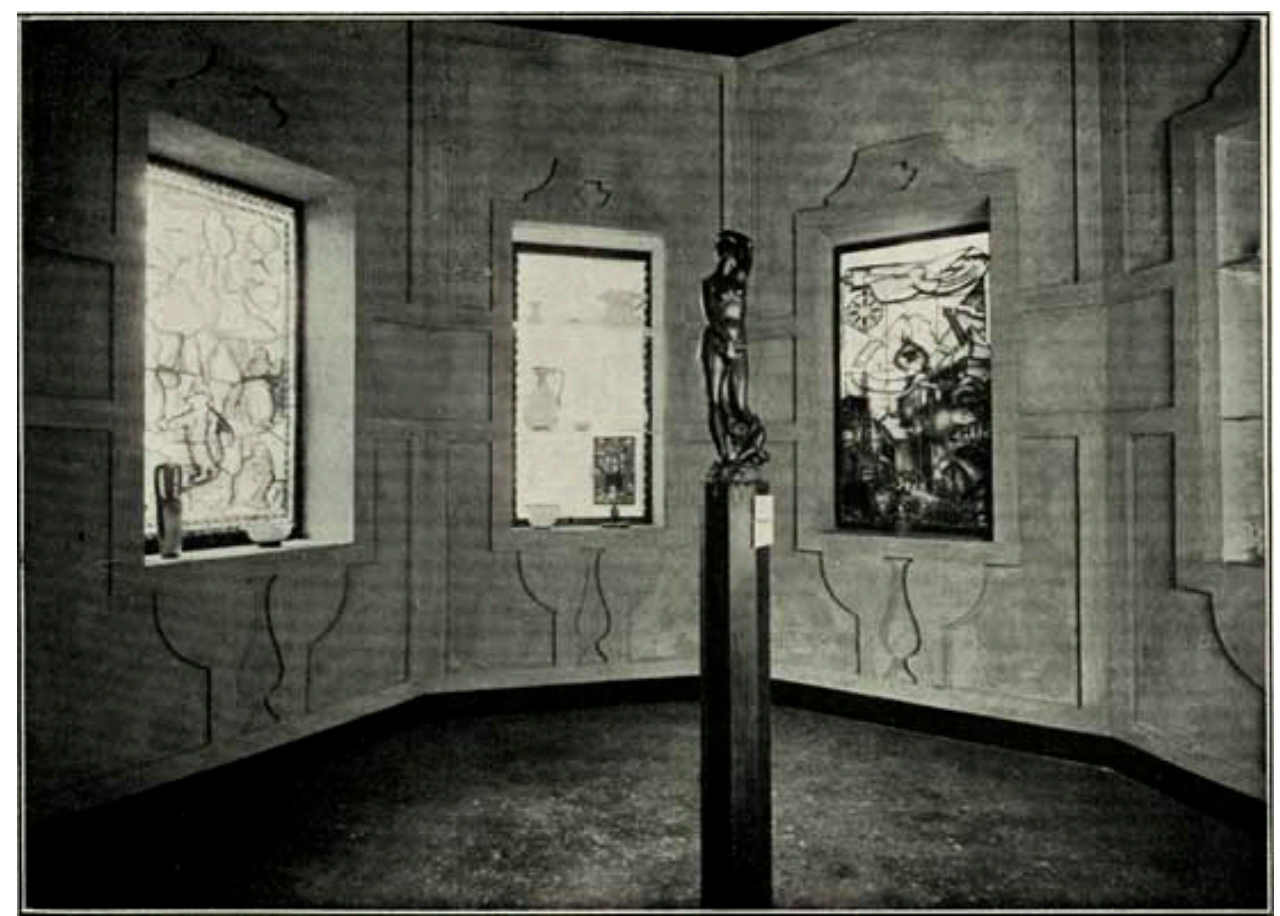

Figure 2. Exhibition hall in the central pavilion of the XVI Biennale di Venezia in La Biennale-Catalogo ufficiale illustrato, ed. Carlo Ferrari, 1928, p. 100.

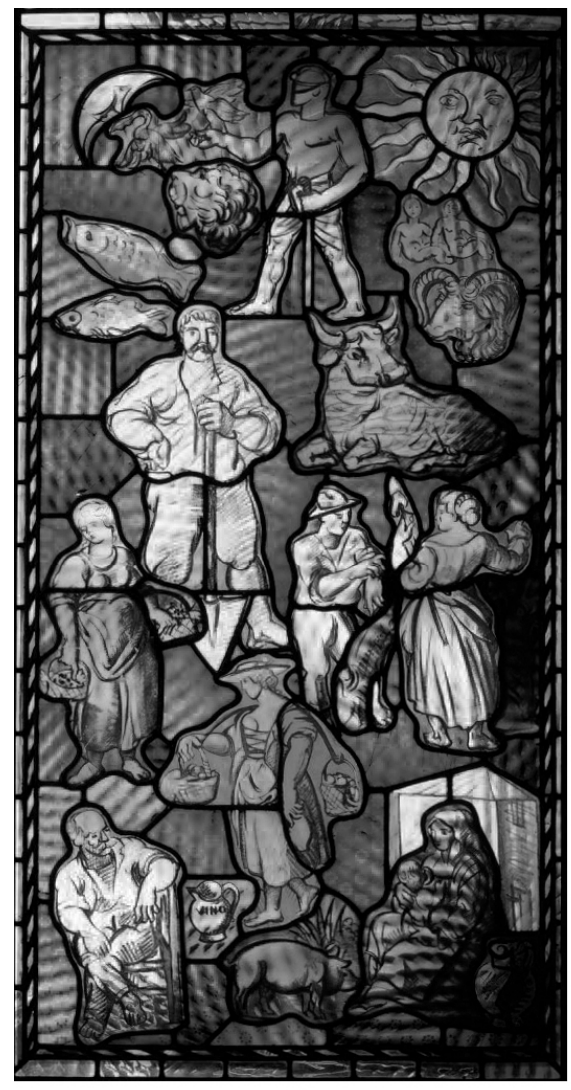

(a)

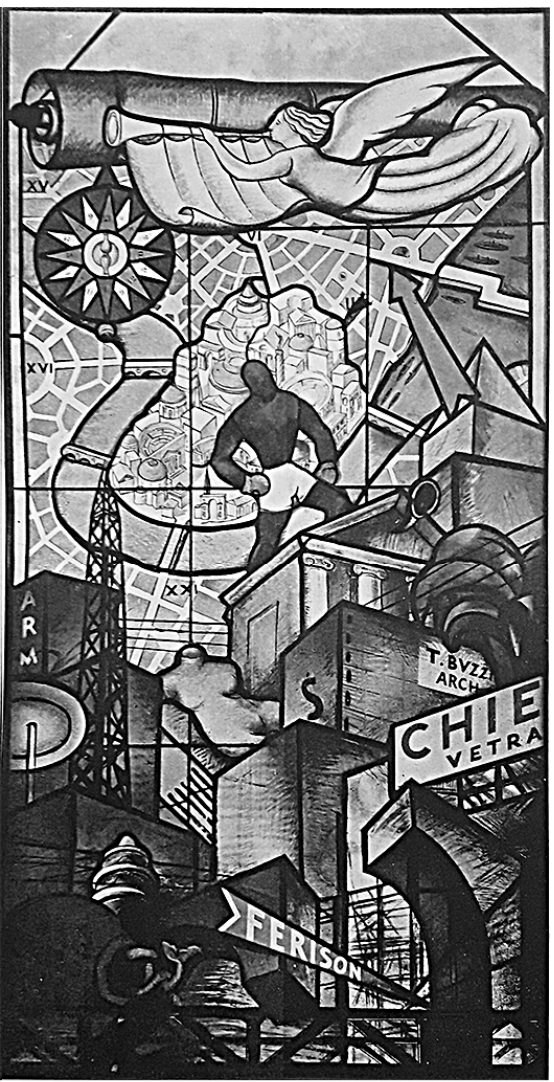

(b)

Figure 3. (a) Pietro Chiesa (excution), composition by Achille Funi, Strapaese, 1928, in «Domus», n. 5, May, 1928, pag. 17. (b) Pietro Chiesa (execution), composition by T. Buzzi, Stracittà, 1928, in «Domus», n. 6, June, 1928, pag. 21. 


\section{The Stairs and the Artifice of Space Illusion}

Pietro Chiesa, «animating» and «untiring performer» [28] of the first Triennale in Monza in 1930, received as exclusive license, room 125, where he exhibited all the work done by the artistic workshop. The wide variety of work presented, ranging from painted glass to that engraved - going through the trials on the curves-showed «an exceptional sensitivity [...] always looking for inventions and discoveries» [29]. The designer's multifaceted personality was even more evident in these occasions where he could easily approach expressive languages of stylistic works far remote from each other. In the room 125, in addition to the already known Strapaese [30] two windows were presented, one engraved on Leonor Fini sketch, the other from the eastern taste drawn by Luciano Pino and a mirror engraved and coloured on Gio Ponti design. The exposure was showing a fruit production of a highly versatile and specialized technical knowledge where, mirrors, bright letters, painted glass, illuminated, perforated and engraved - also on both faces-enchanted the viewer [31]. Of all other nature, the engraving by Tomaso Buzzi (Figure 4), a labyrinth of stairs with clear metaphysical references. From the bottom stand-with the dignity of the ancient splendoursarchetypes that rappresent the melancholic classicism; the temple, the obelisk, the sculptural shapes now blurred by a nature that gradually seems to want to absorb and overcome the glory of the past. This intricate as excessive use of stairs gives rise to a complex decorative motif reminds irregular swastikas, probably inspired by the geometric designs of fabrics and coatings of la Rinascente [32]. The dense spatial plot-even though on a two-dimensional plan-prefigures the dynamic running of the volumes and the complex symbolism recreated by Buzzi in Scarzuola, an evocative, anthropomorphic and allegorical path immersed in nature.

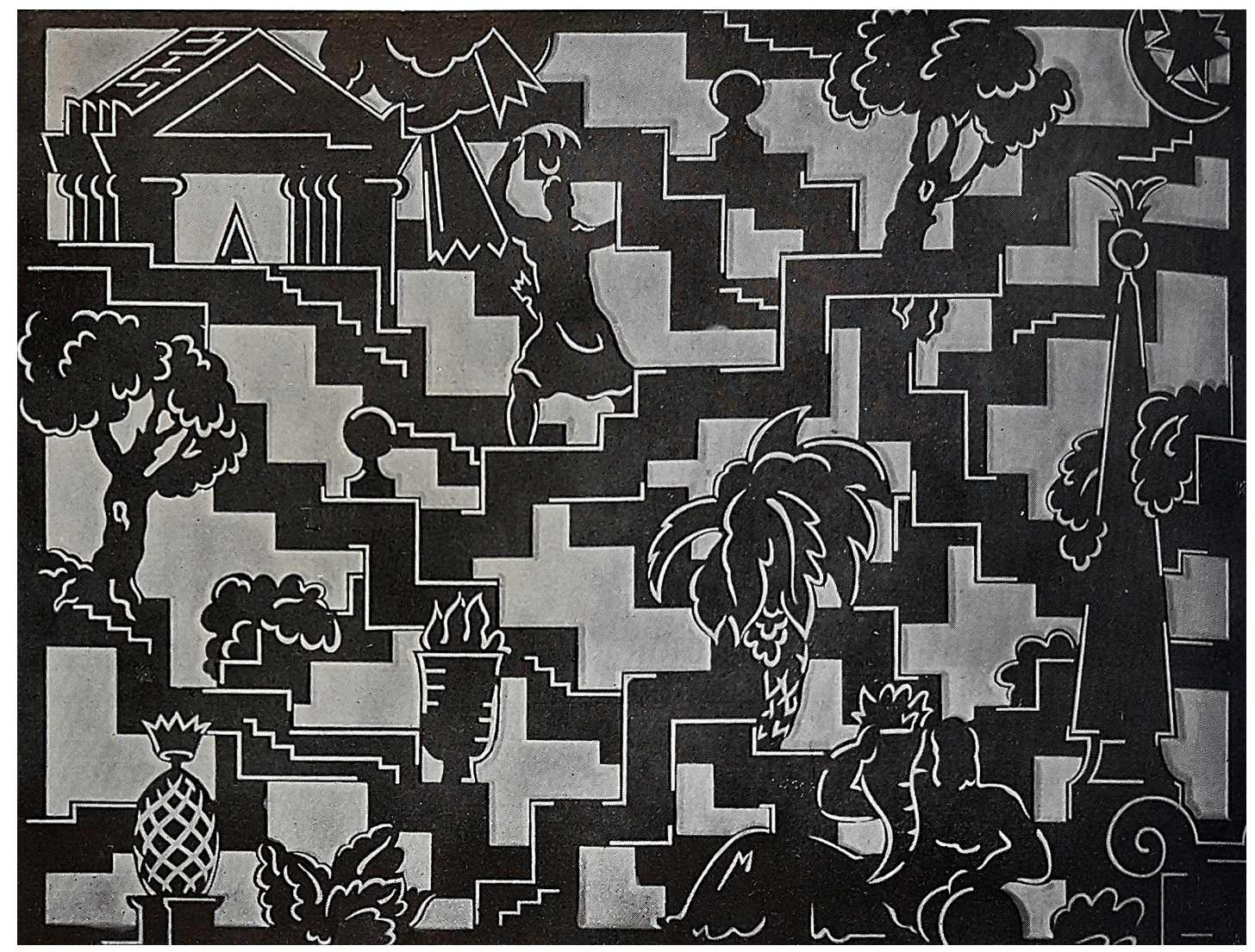

Figura 4. Pietro Chiesa (execution), engraved glass panel, composition by T. Buzzi, 1930.

The arched elements present in the engraved glass, performed by Chiesa, interact with randomly constructed space, taking the distances from the hermetic cypresses of the ideal city. The theme of the stairs anticipates the configuration of buildings such as the Tower of Babel (which encloses the helicoidal musical scale of seven octaves) and the acropolis staircases, true fulcrums of the Buzzi 
town. Inevitable comparisons with more than Maurits Cornelis Escher [33] lithographs notes that some twenty years later resume just the space theme of the stairs amplifying the optical illusion. Considering that the artist has lived in Italy from 1924 until 1935, it is possible that through the press of that time he could have encountered the work carried out by Chiesa designed by Buzzi, or he may have personally met the two designers. Such a spatial dimension is also the references in Giovanni Battista Piranesi [34] inspirer of the "impossible constructions" of Escher and first maker of complex scenes born from the upheaval of the laws of geometry.

It is possible that Buzzi-before the Dutch artist-had got to study the Carceri d'Invenzione, remaining fascinated by the Babel of stairways where the fantastic world is tinged with darkness. The spatial plot in the eighteenth century engravings of the artist assum darker meanings, creating a dreamlike atmosphere and labyrinth from which it seems impossible to break free, where the calculation becomes deception generating anguish and bewilderment. In Scarzuola these surrealistic settings can find a way to live and guide the viewer towards a purification path.

Though some architectural intuitions of the architect already shown in the stained glass presented at the Triennale in Monza in 1930, the construction of the ideal city will not take place before 1958. The association between Chiesa and Buzzi provides an unprecedented reading of the spatial dimension swinging between reality and imagination, the result of a mutual influence based on acute insights and a deep sensitivity to the rising artistic tendencies. The master glassmaker-as careful interpreter of his time-was able to translate onto glass magical and evocative places of the architect's drawings, taking part in a process of hybridization between different artistic genres, a sort of natural trespassing of its powers in other fields. The shared path, thanks to which the two figures suceed in evolving, will have its stumbling block in 1933, when Pietro Chiesa-alongside Gio Pontibecomes artistic director of FontanaArte.

Author Contributions: Francesca Castanò is the author of the paragraph .1 "Introduction" and .2 "From Umbro Landscape towards the Ideal City". Giangaspare Mingione is the author oh the paragraph . 3 "Strapaese and Stracittà: From the Roman Acropolis to the Vertical City" and .4 "The Stairs and the Artifice of Space Illusion".

Conflicts of Interest: The authors declare no conflict of interest.

\section{References and Notes}

1. Ponti, G. Progetto di una finestra arredata, Architettura d'interni ed arredi; Concorsi, progetti e proposte, 1954, accessibile a http://www.gioponti.org/it/archivio. The quote refers to the "La finestra arredata" layout for the X Triennale of Milan.

2. For an overview on the development of artistic shops and glass processing in north-central at the beginning of the twentieth century see F. Castanò; G. Mingione, Le vetrate istoriate di Pietro Chiesa e di Giulio Cesare Giuliani nello spazio liturgico di primo Novecento, VIII Congresso AISU, Napoli, 2017.

3. Cozzolino, S. Mezzo Mediano, Treshould/Seuil/Soglia, Firenze, AlineA, 2013, pp. 14-37.

4. Papini, R. Vetrate di Pietro Chiesa, in «Domus», n. 1, 1929, pag. 23.

5. Castanò, F.; Mingione, G. Pietro Chiesa e l'invenzione della luce tra le due guerre, XXI Convegno Internazionale IPSAPA, Venezia, 2017.

6. Papini, R. Le arti a Monza nel 1927. I. -Gli italiani, in «Emporium», LXVI, 1927, n. 391, pp. 14-32, in particolare p. 22.

7. Giolli, R. Consigli di casa. Vetrate di Chiesa Junior, in «Problemi d'arte attuale», 1928, n. 1, pag. 11.

8. Figure, in «Domus», febbraio, n. 26, 1930, p. 36.

9. Pietro Chiesa took part in the realization of the windows for the Vittoriale from 1923 until 1931 ca. the dense correspondence between the artist and Gabriele D'Annunzio found at the 'General Archives of the Vittoriale (from now on AGV) testifies the result of collaborations and fluctuating relationship between the poet and the designer.

10. The history and evolution of FontanaArte is accurately described in F. Deboni, Fontana arte: Gio Ponti, Pietro Chiesa, Max Ingrand, Torino, Allemandi, 2012.

11. Benjamin, W. Das Passagenwerk, a cura di R. Tiedemann, Gesammelte Schriften, Band V-2, p. 1025, Suhrkamp Verlag, Frankfurt a.M. 1982. 
12. The exhibition was particularly important, from an artistic point of view, because it marked the beginning of the Art Déco; see Bossaglia, R.; Terraroli, V. Milano Deco: la fisionomia della citta negli anni Venti, Skira, Milano, 1999, pp. 96-97, 193-194.

13. P. Chiesa for years will work with Venini, a laboratory that will test the properties of glass and lead to limit the material as in the case of Cartoccio; see Deboni, F., Venini Glass, Torino, Allemandi, 2007.

14. Mancuso, N.F. Il padiglione italiano alla mostra di Parigi, in «L.I.D.E.L.», 15 luglio 1925, pp. 23-25. It is referred to two glass windows with peasants exhibited in Paris, Esplanade des Invalides, stand 5.

15. The composition of the glass panel could be attributed to Tomaso Buzzi, for a careful analysis on the figure of the architect see: Alberto Giorgio Cassani, Tomaso Buzzi: il principe degli architetti (1900-1981), Milano, Electa, 2008.

16. The strange name is used for the first time as a signature to a letter written by P. Chiesa in G. D'Annunzio, «ho constatato che i miei vetri non sanno esser splendenti che alla sua ombra», January 2, 1925, in AGV.

17. For further information about the city ideal T. Buzzi see A. Armati, La Scarzuola: un santuario dimenticato, Perugia, Eleusi, 2012; see Nicoletti, M. Scarzuola: Il sogno ermetico di Tomaso Buzzi, Perugia, Per corsi d'Arte, 2007.

18. Buzzi, T. Lettere, pensieri, appunti. 1937-1979, Cinisello Balsamo, Silvana editoriale, 2000. Reference is made to the note of 21 February 1970.

19. See the Venini \& C. Blown Glasses exhibited at the Biennial of Monza in 1927. A vintage photo immortalizes the striped vessels of Lattimo, and at the bottom stands the monocrome window of P. Chiesa; see Papini, R. Op. cit., p. 25.

20. Ivi, p. 24.

21. Nebbia, U. La quattordicesima Biennale veneziana-le mostre retrospettive-gli scultori nostri-il bianco e nero-un po' d'arte decorativa, in «Emporium», n. 354, Vol. LIX, giugno, 1924, p. 370.

22. Reference is made to exhibition hall description $\mathrm{n} .33$ in La Biennale-Catalogo ufficiale illustrato, ed. Carlo Ferrari, 1928, p. 100. In addition to all of A. Maraini sculpture were present in the room the following window panels: Strapaese (composition by A.Funi), Stracittà (composition by T. Buzzi) e Il sortilegio (composition by Gio Ponti). Also appeared were the pewters made by the dall'Argenteria Italiana Christofle and the glasses executed by VSM Venini and Co. composed by Napoleon Martinuzzi.

23. Maraini, A. L'architettura e le arti decorative alla XVI Biennale Veneziana, in «Architettura ed arti decorative», fascicolo II, ottobre, 1928, p. 59.

24. Rosa, G.T. "Strapaese" e "Stracittà", in «Domus», n.7, Luglio, 1928, pag. 24.

25. Giosuè Carducci in the ode "Davanti San Guido" (1886) published in the collection "Nuove Rime" (1887) alluding to those writers who, extremes Manzoni's teachings, they took refuge in a mannered and contrived prose with polemical tone writes: «la favella toscana, ch'è sì sciocca nel manzonismo de gli stenterelli»; see Chiarini, G. Memorie della vita di Giosue Carducci (18351907) raccolte da un amico, Firenze, Barbera, 1920, pp. 195 e 266.

26. Rosa, G.T. op. cit.

27. It is speculated that the Scarzuola the configuration process is gradual and influenced by commissions and collaborations antecedents see Alberto Giorgio Cassani, op. cit., pag. 103. Crossing the Porta del Cielo, Ianua Coeli, that gives access to the Acropolis, one can observe a particular scene-similar to that of the window performed by P. Chiesa-in which several monuments including the Coliseum, the Parthenon, the Pantheon, the Arc de Triumph, the Pyramid, the Bell Tower (or Tower of the Winds) and the Temple of Vesta coexist with each other in a random order.

28. Ponti, G. L'opera di Pietro Chiesa, Stucchi, Milano, 1949, pag. 4. Pietro Chiesa was one of the most active designers of the Monza Triennale of 1930, exposing several works in the following exhibition halls: 96,101,102,125,165,166. 
29. Reggiori, F. La Triennale di Monza-IV Mostra Internazionale delle Arti Decorative, in «Architettura e arti decorative», fascicolo XI, Luglio, 1930, p. 511.

30. Stained glass window composed by Achille Funi already presented at the Venice Biennale of 1928 was also exhibited at the Triennale of 1930 given its importance.

31. Catalogo ufficiale della IV Esposizione Triennale Internazionale delle Arti Decorative ed Industriali Moderne, Milano, Ceschina, 1930, pp. 165-169-197. The mirrors in the exhibition hall n. 96, "Double bedroom" presented by the company "Maltecca e Taccani", were designed and ordered by arch. T. Buzzi. The bright letters were exhibited in rooms n. 101-102, "Library of a scholar" presented by Publishers Fratelli Treves, Bestetti-Tumminelli, and the Istituto Giovanni Treccan, planned and ordered by Roberto Papini. Chiesa, three years later, it seems to continue albeit at a much smaller scale, the architettura pubblicitaria Fortunato Depero in 1927 had proposed for the Book Pavilion, just for the publishing house Bestetti-Tumminelli. In Room n. 125, Chiesa exhibited the stained glass in collaboration with several designers including A. Funi, L. Fini, L. Pino. M. Campigli, G. Ponti, N. Scolari, T. Buzzi, LM Brunelli, Brothers Cito of Filomarino.

32. Reggiori, F. Op. cit., pag. 485. Reference is made to the old photographs of the "Casa delle vacanze" presented by "La Rinascente" and SA De Angeli-Frua, a project of E. G. Ponti and Lancia.

33. It refers to two works, Casa di scale I and Casa di scale II, both of 1951. MC Escher (1898-1972) lived in Italy from 1924 until 1935, it is conceivable that the artist, by means of press of the time, can be unbeaten in the work done by Chiesa composed by Buzzi.

34. Piranesi, G.B.(1720-1778) made some etchings titled Carceri d'Invenzione between 1745 and 1750 (later versions are dated between 1761 and 1770), which orient in the years to follow the Escher work and its impossible constructions. It's possible that Buzzi may have been inspired by his work. Among the various exhibitions dedicated to the artist stands out the Roman Piranesi of 2017. The utopia factory, edited by L. and S. Ficacci Tozzi, catalog De Luca, 214 pp. 